\title{
THE MINIMUM WEIGHT DESIGN OF A CLASS OF TALL MULTI-STORY FRAMES SUBJECTED TO LARGE LATERAL FORCES-II
}

\author{
By Ryo TANABASHI*, Member of A.I.J. \\ Tsuneyoshi NAKAMURA**, Member of A.I.J.
}

\section{Introduction}

The second part of the present paper presents several particular classes of the minimum weight designs subjected to various restrictions. A simplified and practically useful solution is obtained in Sec. 6. As an example, a 30-story frame of two bays with equal span length is designed for trapezoidally distributed lateral loads.

\section{A class of the minimum weight designs of the frames such that $2 h_{1} \leqq \boldsymbol{l}_{m}$.}

In view of the fact that the Foulkes' mechanism condition has been violated only in the first story columns and that $\psi_{1}$ is large enough to eliminate $\theta_{1}$, it seems appropriate to modify the previous mechanism as shown in Fig. 6, where $\theta_{1}$ does not appear. $\left(\theta_{j}, j \geq 2\right.$ are not shown in Fig. 6) The pattern of the mechanism shown in Fig. 5 (d) is now considered only for that part of the frame which excludes the first story columns. The equal angle of rotation in the plastic hinges formed at all the lower end sections of the second story columns will be denoted by $\psi_{2}$. The equal angle of rotation of all the joints except the first story joints is equal to $\psi_{1}+\psi_{2}$. Corresponding to these modifications, a collapse mechanism of beam type will be necessary for the first story beam with the minimum span length $l_{m}$. This angle of rotation is denoted by $\phi_{m}$. The sums of hinge rotations for the members of the frame may be tabulated as shown in Table 2.

The condition [A] may be satisfied if the angles of rotations are determined as follows.

$$
\begin{array}{lll}
\psi_{1}=h_{1} \Theta, & \psi_{2}=\left(l_{m} / 2-h_{1}\right) \Theta, & \\
\phi_{m}=\left(l_{m} / 2-h_{1}\right) \Theta, & \phi_{k}=\left(l_{k} / 2-h_{1}\right) \Theta, & \phi_{k}=(1 / 2)\left(l_{k}-l_{m}\right) \Theta, \\
\theta_{j}=\left(h_{j} / 2\right) \Theta, & \theta_{2}=(1 / 2)\left(h_{1}+h_{2}-l_{m} / 2\right) \Theta . &
\end{array}
$$

Since all the angles of hinge rotation must be non-negative, the condition [A] can be satisfied by the frames with those span lengths and story heights which satisfy

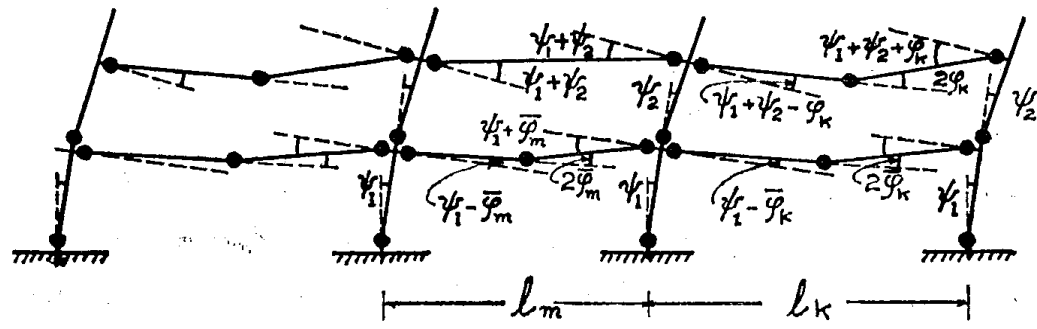

Fig. 6

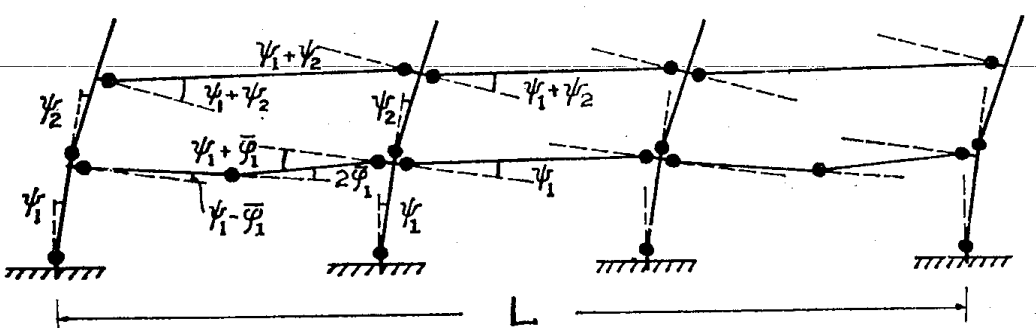

Fig. 7

* Professor of Architecture, Kyoto University, Kyoto

**. Assistant Professor of Architecture, Kyoto University 
TABLE 2

\begin{tabular}{|c|c|c|c|c|}
\hline Member & $\begin{array}{l}\text { Plastic } \\
\text { moment }\end{array}$ & Length & $\underset{j ; k}{\text { Subscripts }}$ & $\begin{array}{l}\text { Sum of hinge } \\
\text { rotations }\end{array}$ \\
\hline$(1, m)$-beam & $B_{1, m}$ & $l_{m}$ & & $2 \phi_{m}+2 \psi_{1}$ \\
\hline$(1, k)$-beam & $B_{1, k}$ & $l_{k}$ & $; k \neq m$ & $2 \phi_{k}+2 \psi_{1}$ \\
\hline$(j, m)$-beam & $B_{j, m}$ & $l_{m}$ & $2, \cdots, f$ & $2 \psi_{1}+2 \psi_{2}$ \\
\hline$(j, k)$-beam & $B_{j, k}$ & $l_{k}$ & $2, \cdots, f ; k \neq m$ & $2 \phi_{k}+2\left(\psi_{1}+\psi r_{2}\right)$ \\
\hline$(1, k)-$ column & $C_{1, k}$ & $h_{1}$ & $; 1,2, \cdots, s+1$ & $\psi_{1}$ \\
\hline$(2, k)$-column & $C_{2, k}$ & $h_{2}$ & $; 1,2, \cdots, s+1$ & $2 \theta_{2}+\psi_{2}$ \\
\hline$(j, k)$-column & $C_{j, k}$ & $h_{k}$ & $3, \cdots, f ; 1,2, \cdots, s+1$ & $2 \theta_{j}$ \\
\hline
\end{tabular}

$$
\left.\begin{array}{l}
2 l_{m} \geq l_{k} \geq l_{m}, \quad 4 h_{1} \geq l_{k}, \\
2\left(h_{1}+h_{2}\right), \quad 4 h_{1} \geq l_{m} \geq 2 h_{1} .
\end{array}\right\}
$$

Corresponding to this modified overcomplete collapse mechanism, the design must be modified as follows. First, the general procedure of the previous section may be applied only to that part of the frame which excludes the first story beams and columns. Secondly, all the first story beams shall be so designed as to collapse under the vertical loads with plastic hinges formed at their midspans and both ends. Thirdly, the first story columns may be designed almost in any manner to carry the shear resultant so far as the assigned plastic moment of each column exceeds the moment at its top end in conformity with

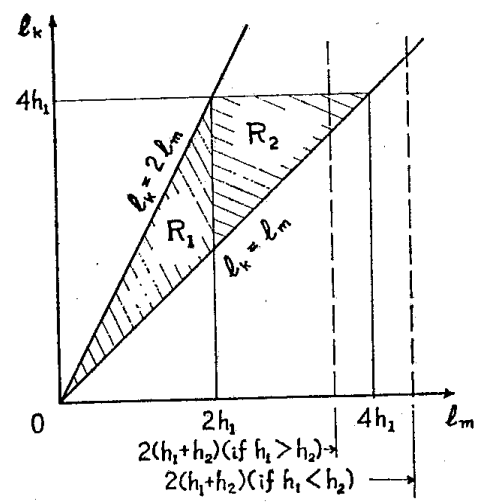

Fig. 8 the direction of the hinge rotation. This is due to the fact that the first story columns have the same length and that the weight function is linear.

For a frame of single span, the frame moments are uniquely determined only by (3) and the solution for this case will be included in Sec. 6 .

The regions of $l_{m}$ and $l_{k}$ for which the minimum weight designs have been obtained, may be represented as Fig. 8. The region $R_{1}$ is defined by the restriction (12), whereas $R_{2}$ by (13). In view of the restrictions in terms of $h_{1}$ and $h_{2}$, it may be well expected that a similar modification may be extended to the remaining region of $l_{k} \geq l_{m}>0$.

\section{Frames with equal span length.}

Consider a special class of frames such that $l_{k}=l$ for all $k$. The linearized weight function (5) may then be written as

$$
G=g\left[\sum_{j=1}^{f} 2 h_{j}\left(\sum_{k=1}^{s} M_{j, k}\right)+l\left(\sum_{k=1}^{s} M_{1, k}\right)+2 l \sum_{j=2}^{f}\left(\sum_{k=1}^{s} M_{j, k}\right)\right]
$$

Substitution of (3) into (14 a) furnishes

$$
G=g\left[\sum_{j=1}^{f}(1 / 2) h_{j}^{2} \sum_{i=j}^{f} P_{i}+(1 / 4) l h_{1} \sum_{i=1}^{f} P_{i}+(1 / 2) l \sum_{j=2}^{f} h_{j} \sum_{i=j}^{f} P_{i}\right]
$$

In other words, the weight is uniquely determined only by (3), without regard to the other constraints (4). This implies the following geometrical significance. The weight hy perplane is parallel to the intersection of $f$ hyperplanes defined by (3). The constraints (4) truncate this in tersection. $G$ achieves the minimum weight when it coincides with this intersection bounded by (4). Unless this bounded intersection is a point, any point therein represents a minimum weight design. Even though $G$ is unique, there exist many minimum weight designs. The corresponding overcomplete collapse mode need not include the beam type mechanism such as shown in Fig. $5 \mathrm{c}$. The Foulkes' mechanism condition may readily be examined for both of the case $2 h_{1} \geq l$ and the case $2 h_{1} \leq l$. Included in this class of designs is the special case where

$$
M_{j, k}=M_{j} \text { for all } \mathrm{k} \text { with the same } j \text {, }
$$

satisfying all the constraints (4). This is a design such that all the beams and all the internal columns in a story have the same plastic moments, respectively and that the two external columns in a story 
have half the plastic moment of the internal columns in the story.

6. Frames such that $M_{j, k}=M_{j}$ for all $k$ with the same $j$.

The aforementioned simple example leads us to the special class of designs for the case of unequal span lengths such that

$$
M_{j, k}=M_{j} \text { for all } k \text { with the same } j
$$

This implies that all the beams in a story have to be assigned the same plastic moment and altogether form a large total span with the length defined by $L=\sum_{k=1}^{s} l_{k}$, and that, in view of eqs. (1), the plastic moment of an internal column in a story must be twice as large as that of the external columns in the story. In view of (15), the equations of sway equilibrium (3) may be written as

$$
M_{j}=\left(h_{j} / 4 s\right) \sum_{i=j}^{f} P_{i}
$$

Substitution of eq. (16) into the weight function (5) provides

$$
G=g\left[(1 / 2) \sum_{j=1}^{f} h_{j}^{2} \sum_{i=j}^{f} P_{i}+(L / 2 s) h_{1} \sum_{i=1}^{f} P_{i}+2 \sum_{j=2}^{f} h_{j} \sum_{i=j}^{f} P_{i}\right]
$$

Thus $G$ is uniquely determined only by eq. (16) as far as the constraints (4) are all satisfied. The corresponding plastic moments are given by

$$
\left.\begin{array}{l}
B_{j}=(1 / 4 s)\left(h_{j} \sum_{i=j}^{f} P_{i}+h_{j+1} \sum_{i=j+1}^{f} P_{i}\right) \\
C_{j}=(1 / 2 s) h_{j} \sum_{i=j}^{f} P_{i}, \quad \widetilde{C}_{j}=(1 / 4 s) h_{j} \sum_{i=j}^{f} P_{i}
\end{array}\right)
$$

where $B_{j}, C_{j}$ and $\widetilde{C}_{j}$ denote the plastic moments of the $j$-th story beam, internal column and external column, respectively.

Since there are only three different plastic moments in a story, the $3 f$ sums of hinge rotations for the $3 f$ spans must satisfy the Foulkes' mechanism condition. These sums are tabulated in TABLE 3.

TABLE 3

\begin{tabular}{l|c|l|l}
\hline \multicolumn{1}{c|}{ Member } & $\begin{array}{c}\text { Plastic } \\
\text { moment }\end{array}$ & Length & \multicolumn{1}{c}{$\begin{array}{c}\text { Sum of hinge } \\
\text { rotations }\end{array}$} \\
\hline Beam & $B_{j}$ & $L$ & $2 s \psi_{1}$ \\
Internal column & $C_{j}$ & $(s-1) h_{j}$ & $2(s-1) \theta_{j}$ \\
& $C_{1}$ & $(s-1) h_{1}$ & $(s-1)\left(2 \theta_{1}+\psi_{1}\right)$ \\
External column & $\widetilde{\boldsymbol{C}}_{j}$ & $2 h_{j}$ & $4 \theta_{j}$ \\
& $\widetilde{\boldsymbol{C}}_{1}$ & $2 h_{1}$ & $4 \theta_{1}+2 \psi_{1}$ \\
\hline
\end{tabular}

The Foulkes' condition can be satisfied if we determine $\psi_{1}$ and $\theta_{j}$ as follows.

$$
\psi_{1}=(L / 2 s) \Theta, \quad \theta_{j}=(1 / 2) h_{j} \Theta, \quad \theta_{1}=\left(h_{1} / 2-L / 4 s\right) \Theta
$$

In view of the limiting value of $\theta_{1}$, the present design gives the minimum weight for the frames satisfying

$$
2 h_{1} \geqq L / s
$$

This condition corresponds to the previous limitation (12). A slight modification is necessary for those frames in which the restriction (19) is violated. The same technique as in Section 4 may be employed again to obtain the modified mechanism shown in Fig. 7. The symbols similar to those used in Fig. 6 are employed here in Fig. 7. Each first story beam carries a different vertical load and has the limiting smallest value to which its plastic moment may be reduced in order to achieve the minimum weight. Now that all the first story beams are to be assigned the same plastic moment here, the actual limitation is given by the largest value among all these limiting smallest values. As soon as the plastic moment of the first story beam is reduced to this largest value, there exists at least one beam at whose midspan a plastic hinge may form. Let $\vec{s}$ be the number of beams of the first story at whose midspans plastic hinges may form. Let this angle of hinge rotation be $2 \phi_{1}$. The sums of hinge rotations of the members may then be tabulated as in Table 4. 
TABLE 4

\begin{tabular}{l|l|l|l}
\hline \multicolumn{1}{c|}{ Member } & $\begin{array}{c}\text { Plastic } \\
\text { moment }\end{array}$ & Length & \multicolumn{1}{c}{$\begin{array}{c}\text { Sum of hinge } \\
\text { rotations }\end{array}$} \\
\hline \multirow{2}{*}{ Beam } & $B_{j}$ & $L$ & $2 s\left(\psi_{1}+\psi_{2}\right)$ \\
& $B_{1}$ & $L$ & $2 s \psi_{1}+2 \vec{s} \phi_{1}$ \\
Internal column & $C_{j}$ & $(s-1) h_{j}$ & $2(s-1) \theta_{j}$ \\
& $C_{2}$ & $(s-1) h_{2}$ & $(s-1)\left(\psi_{2}+2 \theta_{2}\right)$ \\
& $C_{1}$ & $(s-1) h_{1}$ & $(s-1) \psi_{1}$ \\
& $\widetilde{\boldsymbol{C}}_{j}$ & $2 h_{j}$ & $2 \theta_{j}$ \\
& $\widetilde{\boldsymbol{C}}_{2}$ & $2 h_{2}$ & $2 \psi_{2}+4 \theta_{2}$ \\
& $\widetilde{\boldsymbol{C}}_{1}$ & $2 h_{1}$ & $2 \psi_{1}$ \\
\hline
\end{tabular}

In order that the Foulkes' condition be satisfied, $\psi_{r_{1}}, \psi_{2}, \phi_{1}$ and $\theta_{j}$ must be given by

$$
\left.\begin{array}{l}
\psi_{1}=h_{1} \Theta, \quad \psi_{2}\left(L / 2 s-h_{1}\right) \Theta, \quad \phi_{1}=(1 / \vec{s})\left(L / 2-s h_{1}\right) \Theta, \\
\theta_{j}=(1 / 2) h_{j} \Theta, \quad \theta_{2}=(1 / 2)\left(h_{1}+h_{2}-L / 2 s\right) \Theta .
\end{array}\right\}
$$

All the hinge rotations are non-negative for the frames satisfying the conditions

$$
2\left(h_{1}+h_{2}\right) \geq L / s \geq 2 h_{1}, \quad 2(s+\bar{s}) h_{1} / s \geq L / s
$$

These are the restrictions corresponding to $(13)$.

\section{Example:30-story frame of 2 bays.}

A 30-story frame of two bays with equal span length carrying equal vertical loads shown in Fig. $9 \mathrm{~b}$ is designed for the lateral forces distributed as shown in Fig. $9 \mathrm{a}$, where the base shear coefficient

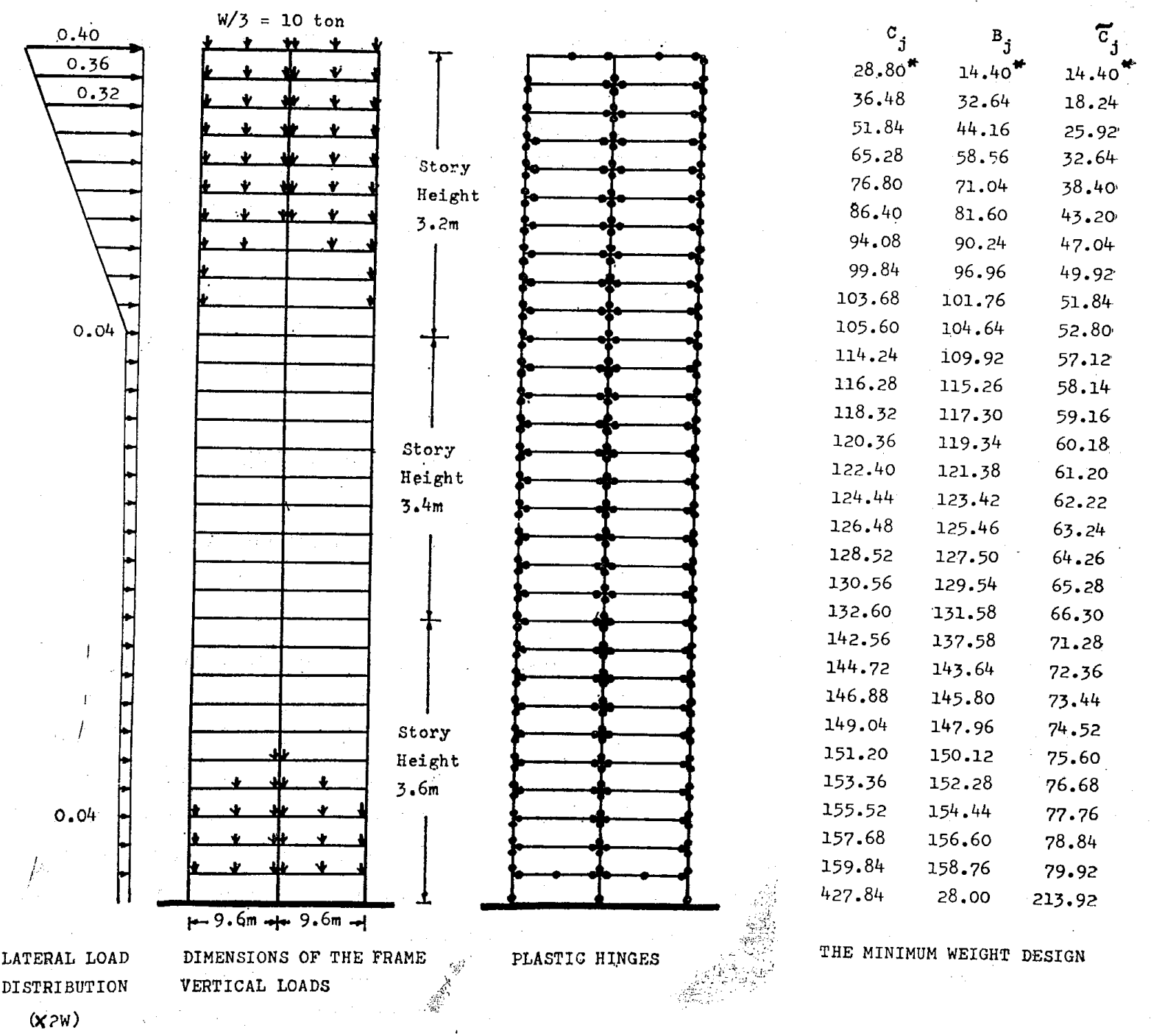

FIG. 9 THE MINIMUM WEIGHT DESIGN OF A 30-STORY FRAME OF TWO EQUAL SPANS 
is 0.10 . The plastic moments obtained from the general solution (17) are tabulated in Fig. 9 . The numbers with asterisks in the plastic moments indicate the modified design of the topmost story members by means of plastic moment distribution. In order to restrict the modification as locally as possible, plastic moment distribution has been carried out under the constraint that the lower end section of the internal column of the topmost story is to be assigned the plastic moment twice as much as that of an external column.

\section{Concluding remarks.}

The present paper has established the minimum weight design of a broad class of tall multi-story frames of practical interest in an extremely simple and explicit form. The theoretical solution serves to clarify the general features of the minimum weight designs of regular multi-story frames subjected to comparatively large lateral shear. It should be remarked that all the beams except those with the minimum span length are designed to carry the vertical loads in their respective spans, and that the corresponding bays contribute little to supporting the lateral shear. The bays with the minimum span length must then be designed to carry the remaining part of the lateral shear resultant. This result appears to suggest, from economic point of view, the use of shear walls or bracings. It is however noted that in certain cases the present solution results in columns of zero plastic moments. Even if the columns are to be augmented by taking into account the effect of axial forces, this theoretical solution may in some cases appear to be unpractical in view of the elastic-plastic instability just prior to collapse. Hence the paper has explored some special classes of restricted minimum weight designs.

The present design must next be modified for the effect of axial forces within the simple plastic theory. The simple plastic design so constructed must then be augmented against the effect of additional moments induced by the large elastic-plastic deformation under the presence of large axial forces. Then the ultimate strength design within the second order theory may be established. This approach has been suggested by the present authors in Ref.[15] recently and appears to be practically useful in its simplicity and directness.

\section{Acknowledgments.}

The authors would like to thank Professor Y. Yokoo of Nagoya University for his helpful advice and encouragement. The authors are also indebted to Professor H. Tanaka of University of Tokyo who offered several helpful criticisms at an early stage of the present manuscript.

\section{REFERENCES}

1. Heyman, J., "Plastic Design of Beams and Plane Frames for Minimum Material Consumption," Quart. Appl Math., Vol. 8, 1951, p 373

2. Foulkes, J., "Minimum Weight Design and Theory of Plastic Collapse," Quart. Appl. Math., Vol. 10, p 347

3. Foulkes, J., "The Minimum Weight Design of Structural Frames," Proc. Royal Society, Ser. A, Vol. 223, 1954, p 482

4. Livesley, R.K., “The Automatic Design of Structural Frames,” Quart. J. Mech. Appl.Math., Vol. 9, 1956, p 257

5. Heyman, J. and W. Prager, "Automatic Minimum Weight Design of Steel Frames," J. Franklin Inst., Vol. 226, No. 5, Nov. 1958

6. Stone, R.L., "Automatic Minimum Weight Design of Steel Frames on the IBM 650 Computer," Brown University Tech. Rep. IBM 2038/2, 1958

7. Kalker, R.L., "Automatic Minimum Weight Design of Steel Frames on the IBM 704 Computer," Brown University Tech. Rep. IBM 2038/3, 1958

8. Tanaka, H., "Automatic Analysis and Design of Plastic Frames," Report of Inst. Indust. Sci., Univ. of Tokyo, Vol. 12, No. 3, 1962

9. Prager, W., "Minimum Weight Design of a Portal Frame," Proc. ASCE, Eng. Mech. Div., Paper 1073,1956

10. Discussions on "An Approach to the Design of Tall Steel Buildings," Proc. Inst. Civil Engrs. Vol. 18, 1961, p 832 
11. See for instance, M.R. Horne, “The Stability of Elastic-plastic Structures," Progress in Solid Mechanics, Vol. 2, Chap. VII, 1961

12. See for instance, L.S. Beedle, "Plastic Design of Steel Frames," Chap. 3; 1958, p 79

13. Tanabashi, R. and T. Nakamura, "The Simplified Minimum Weight Design of Tall Multi.story Frames Subjected to Lateral Forces", Proc. of 1963 Kinki Branch Convention of A.I.J.

14. Tanabashi, R. and T. Nakamura, On the Minimum Weight Design of Tall Multi-story Frames Subjected to Lateral Forces," Proc. of 1964 Kinki Branch Convention of A.I.J.

15. Tanabashi, R. and T. Nakamura, "An Approach to the Last Hinge Point Design of Tall Multi-story Frames," Proc. 11-th Conference on Bridge and Structural Engineering, "Structural Design of Tall Multi-story Buildings and Long Span Structures," Nov. 1964, Tokyo, The Committee on Bridge and Structural Engng., Japanese Congress of Sciences

16. See for instance, S. Vajda "The Theory of Games and Linear Programming", Methuen \& Co. Ltd., 1956, (Translated into Japanese by T. Miyashita, 1959) 


\section{大きな水平力をうける 1 クラスの高層架構の最小重量設計-II}

$\begin{array}{llll}\text { 正会員 棚 } & \text { 橋 } & \text { 諒* } \\ \text { 正会員 中 } & \text { 村 恒 } & \text { 善水 }\end{array}$

序 本論(II) は種々の制限条件の下における特別なク ラスの最小重量設計の解を提供する。簡潔かつ実際上便 利な解が 6 で得られる。例として，2等長スパンの30層 架構が台形分布の水平力に対して設計される。

\section{4. $2 \boldsymbol{h}_{1} \leq \boldsymbol{l}_{m}$ の場合の最小重量設計 前節において} Foulkes の機構条件が 1 階柱においてのみ満足されず, $\psi_{1}$ が $\theta_{1}$ を必要としない程度に小でなりればならなかっ た。従って前記過完全崩壊機構を，最下層で $\theta_{1}$ のない 図 6 の如き機構に修正する。この場合前の $\psi_{1}$ の役割を 演ずるように 2 階柱脚に $\psi_{2}$ の sway 用の関節回転角を $\theta_{2}$ の他に与光，2階以上の節点回転角を $\psi_{1}+\psi_{2}$ とす る。刘态して 1 階の $l_{m}$ 長さの梁の中央にも関節形成を 考える必要がある。このように修正すれば，各部材毎の 関節回転角の和法, 表 2 で与光られ, 条件 $[\mathrm{A}]$ 性(13)式 の満足されるクラスの架構について満足させ得る。かよ うな修正機構に対応して, 塑性モーメントの割当ても次 のように修正されねばならない。第 1 亿前節の一般解形 式は 1 階梁, 柱以外についてのみ適用される。第 2 に, $l_{m}$ も含めてすべての 1 階梁は材端及びスパン中央にお いて関節が形成されるように設計され，更に 1 階柱は柱 脚にのみ関節が形成されるようにかつ層せん断力に対抗 し得る限り任意に設計されてよい。このようにして最小 重量設計が得られた範囲を図示すると図 8 の斜線部分と なる。但し $R_{1}$ は(12)の制限による範囲， $R_{2}$ は(13)に よる範囲で， $R_{2}$ 注鉛直点線で示される制限線で削られ る事もある。 $h_{1}, h_{2}$ に詨する制限から見て，これ以外の クラスの架構についても類似の修正によって, 解の得ら れる領城は逐次拡張されよう。

5. 等張間の架構 すべての $k$ てついて $l_{k}=l$ であ るような特別な架構を考える。この時 $G$ は (14a)式で 表現され，(3)を(14a) に代入すると (14b) 式のよら に，重量が(3) のみで決定されてしまう結果を得る。こ れは次のような幾何学的意味をもつ。即ち $f s$-空間にお いて, 重量超平面は(3)で定義される $f$ 個の超平面の共 通部分に平行であって, 制約条件 (4) 注この共通部分の 許容範囲を定義する。Gはこの共通部分に一致する時に 最小值に達する。この共通部分の許容範囲が点である場 合以外は，その中の点で表現されるいかなる設計む同一 の最小重量を与える。対応する過完全崩壊機構江図 $5 \mathrm{c}$

* 京都大学教授・工博

** 京都大学助教授

(昭和 40 年 10 月 16 日本稿受理, 討諭期限昭和 41 年 6 月末日)
の梁型関節を含む必要はない。Foulkes の機構条件は $2 h_{1} \geq l, 2 h_{1} \leq l$ のいずれの場合も容易に検討され得 る。その設計の一つの特別な場合として各階每に構モ一 メントが等しい場合がある。但し（4）满足されねばな らない。この時, 各階毎に梁と内柱はそれぞれ同一の塑 性モーメントの割当となり, 外柱は内柱 $1 / 2$ の塑性モ一 メントの割当となる。

\section{6. 各階毎に構モーメントが等しく割当てられた架構}

等張間でなくてかつ各階每に構モーメントが等しいとい ら制限条件を満足する架構を考える。これはとりもなお さず，前記の如く，各嘴每に梁と，内柱とが，それぞれ 同一の塑性モーメント，外柱は内柱の $1 / 2$ の塑性モーメ ントを割当てるとして，重量最小化を考えることを意味 する。即ち Foulkes の機構条件検討の際には，梁長は $L=\sum_{k=1}^{s} l_{k}$ であり, 内柱は $(s-1) h_{j}$, 外柱は $2 h_{j}$ の長さ を有するとして取扱わね孙ならないことになる。この場 合，(16) 式のように表現できる層方程式を(5) に代入す ると，5節と同様，重量は，(4a) の満足されている荷 重の組に対して，(16)のみで一意に決定される。対応す る塑性モーメントはで (17) 与えられる。

各階について上記の如く 3 個の異るスパンがあるか ら, $3 f$ 個のスパン長に刘する $3 f$ 個の関節回転角総和 の比が Foulkes の機構条件を満足していなければなら ない。これらは表 3 に示される如くであって，(19)式を 満足する架構については，(18)式のように条件[A]を満 足させ得る。前記一般の場合に対する制限(12)に対応す るこの場合の制限が(19)式である。

(19)式の満足されない架構では，4節で図 6 の修正機 構を考えたのと同様に，この場合図 7 に示寸修正機構を 考える。しかし，1階の各梁は異る鉛直荷重を支持せね ばならず，徒って塑性モーメントの限界最小值む異る。 所で一階の梁がすべて同一の塑性モーメントを割当てら れるとすると，㝣際の最小值は，上記の 1 階各梁の限界 最小值の中の最大值で与えられることになる。もし1階 梁の等しい塑性モーメントが丁度この限界值に減少せし められると，少くとも 1 個の梁のスパン中央に関節が形 成されてよい状態になる。今このようにスパン中央に関 節形成され得る 1 階梁スパン数が $\bar{s}$ 個あるとし，その関 節回転角を $2 \phi_{1}$ で表わせば，各部材毎の 関節回転角和 は表 4 で与えられる。従って(21)式で与えられる条件を 満足する架構については(20)式の如くに Foulkes 条件 
を満足させ得る。この制限(21)は一般の場合の制限(13) と対応するものである。

7. 例 : 等スパン 30 層架構 図 9 亿示す水平力と鉛 直荷重を支持する 2 等スパン長の 30 層架構の最小重量 設計を考える。前述の如く，一般解(10)式が軸力の考慮 々弾塑性安定性の観点から必らずしも現実に受入れ得る ものではないので，この場合に対して(17)式の解を採用 すれば，図 9 右側に示すような塑性モーメントの割当て が得られる。*印を附した数值は，最上階で前記制限条 件 (4) が乱されるので，それより下層の修正を伴わない ように塑性モーメント分配法で修正したものである。単 純理論の範囲で, 軸力を考慮して上の設計を修正する方 法は，文献[15]にも述べたように，上記崩壊時の $M$ 分布 に対応する軸力を求めて, 各部材について曲げモーメン 卜と軸力の両者が作用する時の降伏条件式に代入してそ の断面の塑性モーメントを新たに決定することである。

8. 結語 本論によって, 実際上興味あるクラスの 滈層架構の最小重量計の一般解が非常に簡潔から explicit な形式で求められ, その性格, 特徴が明らかにされ 得た。注目すべきは, 最も一般的な場合の解(10)の形式 においては, 最小スパン長以外の梁はそれぞれのスパン の鉛直荷重を主として支持するように，また最小スパン
長の梁とこれらに連結する柱は層せん断力の残りの部分 を全部支持するように設計されることが要求される点に ある。この結果は，水平力が各柱梁で支持されるより は，集中的な水平力支持体を作る方が経済的であること を示していると思われる。しかしながらその結果，ある 場合には塑性モーメント割当量が零の柱が, 解として得 られるし，一般に柱の設計が極端に不釣合になるようで ある。たとえ，単純理論の範囲内で軸方向力に対して修 正するとしても，なお極端に異る柱設計は非実際的と見 られる。そこで本論のIIでは，このような不釣合な設計 とならないような制限付最小重量設計の解(17)式を求め たのである。これに刘する計算例としての 30 層架構の 設計には従って上記の困難点は現れていない。

実際の設計上は，(17)式の解も，前述の如く，まず第 1 亿笚純理論の範囲内で, 降伏条件に軸力向力を考慮し て修正されね杖ならない。更にこのような単純理論によ る設計は, 崩壊点近傍における大きな層変位と, 大きな 軸方向力によって生ずる附加モーメントの影響に対 して も十分増強されねばならない。かくて初めて二次理論に おける終局強度設計が確立され得る。このようなアプロ 一チは，既に筆者が文献[15]で最近提唱した所である。 
curvature integration is readily accomplished by electronic digital computor and be applicable to any practic section

\title{
DYNAMIC CHARACTERISTICS OF STACK-LIKE STRUCTURES
}

\author{
by HIRoyoshi Kobayashi, Assistant Prof., Tokyo Institute \\ of Technology Member of A.I.J., HAJIME HIRAKAWA. \\ Graduate Student, Tokyo Institute of Technology Member \\ of A.I.J.
}

Authors studied a calculation method on tapered stack, to obtain the natural frequencies and mode shapes 0 bending vibration, of which cross section varies freely in height, and this paper is the first report of a series 0 the dynamic response analysis of stack-like structures due to earthquake.

They carried out the analysis, regarding the stack as a continuous bending vibration system, not as a concen trative mass system, by numerical computation. To simplify the analysis, they assumed as follows;

a) The stack is resisted only by the bending moment and there are no effects' of gravity and shearing deforma tion.

b) The stack is rigidly fixed at base.

c) The stack has a constant cross section in each devided part.

With these assumptions, the equations of natural frequencies and mode shapes of a stack are defined by the following equations;

$$
G \cdot \bar{H}=\bar{H} / w^{2}
$$

where $G, \bar{H}$ and $w$ represent the matrix of coeffieients, the column matrices of mode shape and the natural frequency respectively.

These results are compared with the results of Stodola's method, Mononobe's method, Naruoka's method and Ishizali's experiments. All these results (shown in Table 4) show that natural frequencies of stacks will be computed well approximately; for practical purposes, by this method.

In this study they used the digital computer FACOM 222, Tokyo Institute of Technology.

U.0.C. $624.042 .7: 624.043$

\section{THE MINIMUM WEIGHT DESIGN OF A CLASS OF \\ TALL MULTISTORY FRAMES SUBJECTED TO LARGE LATERAL FRAMES (II) (See Page 37)}

by Dr. RYO TANABASHI, Prof. of Architecture Kyoto University, Kyoto, TSUNEYOSHI NAKAMURA, Assistant Prof. of Architecture, Kyoto University Members of A.I.J.

U.D.C. 711.433

\section{STUDIES ON THE SIZE OF CITY (4)}

by TAKAMASA YOSIZAKA, Prot. of Waseda Univ., KOITI TONUMA Research Student of Waseda Univ. Members of A.I.J.

This report is the fourth part of the series of studies on the size of city.

In this report, we take up the third Block which is enclosed by main trank line of road, and public space (school, hospital, green, goverment office, factory; traffic, commarcial zone)

Through the studies on the size of city (1), (2), (3), (4), finally we have classified each physical structure of cities Japan, and made model type of them basing on potenciality or strength of city.

U.D.C. $628.9 .001: 711.81: 333.32$

\section{DISTRIBUTIONS OF DWELLING-UNIT-SPACE ( 3 )}

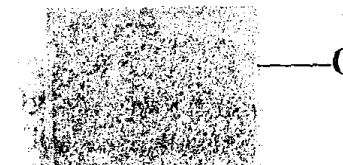

On distribution type of living spaces and its changing trend-

by TSUNESHI MIWA Member of J.H.C., Member of A.I.J.

W 1 He ota from census and housing survey, the distributin type of living spaces well fits in Gibrat distribution (lognormal distribution).

This report is about the " $\tau$ " (deviation) and the " $m$ " (mean) of Gibrat distribution on the number of tatami (living space) in dwellings and households. 